Research Article

\title{
Acute Toxicity and Outcomes of Radiation Alone Versus Concurrent Chemoradiation for Locoregional Advanced Stage Cervical Cancer
}

\author{
Efek Toksisitas dan Respons terhadap Terapi Radiasi dibandingkan dengan \\ Kemoradiasi Konkuren pada Kanker Serviks Lokoregional Stadium Lanjut
}

\author{
Rudy Gunawan ${ }^{1}$, Laila Nuranna1, Nana Supriana ${ }^{2}$, Bambang Sutrisna ${ }^{3}$, Kartiwa H. Nuryanto ${ }^{1}$ \\ ${ }^{1}$ Division of Oncology Gynecology \\ Department of Obstetrics and Gynecology \\ ${ }^{2}$ Department of Radiotherapy \\ ${ }^{3}$ Department of Epidemiologic \\ Faculty of Medicine University of Indonesia/ \\ Dr. Cipto Mangunkusumo Hospital \\ Jakarta
}

\begin{abstract}
Objective: To evaluate and determine the toxicity and outcomes in patient receiving radiation (RT) alone versus concurrent chemoradiation (CRT) using cisplatin for locoregional advanced cervical cancer in Dr. Cipto Mangunkusumo Hospital (RSCM).

Methods: Simple randomized single-blind clinical study, done during the period of November 2010-April 2011, in 32 patients with locoregional advanced cervical cancer (16 were treated RT alone and the rest is treated with CRT). Teletherapy was administrated using ${ }^{60}$ Co Gamma Rays 1.3 MV and photon beam linear accelerator 4-10 MV. The radiation was administered as much as 2.0 Gy per fraction daily for 5 days/week, for the total of 25 fractions. Brachytherapy was performed using HDR after-loading method, with Microselectron plane radiation source 129 , as much as $3 \times 7$ Gy doses to point A. CRT using cisplatin $30 \mathrm{mg} / \mathrm{m}^{2}$ were given for 5 series during the radiotherapy course. The toxicity assessments were carried out each week, up until 3 months after the therapy was deemed completed based on the RTOG and ECOG criteria.
\end{abstract}

Results: We acquired $100 \%$ complete response in both the CRT and RT groups. In the CRT group, we found acute gastrointestinal toxicity grade $3(18.75 \%)$ and grade $2(43.75 \%)$; acute genitourinary toxicity grade $3(25 \%)$, grade $2(31.25 \%)$; and acute hematological toxicity grade $3(12.50 \%)$ and grade $2(25 \%)$. It is contrasted with the RT group, in which we did not found any cases of acute gastrointestinal toxicity, genitourinary or acute hematologic toxicity. The overall time treatment (OTT) of 56-58 days in CRT and RT group were $25 \%$ vs. $81.25 \%$ respectively, and the OTT of 59-70 days in CRT and RT group were $75 \%$ vs. $18.75 \%$, respectively.

Conclusion:The response to CRT and RT for locoregional advanced cervical cancer was not different in 3 month evaluation. Acute gastrointestinal, genitourinary, and hematologic toxicities found in CRT were higher than in RT ( $\mathrm{p}=0.000 ; \mathrm{p}=0.000 ; \mathrm{p}=0.002)$.

[Indones J Obstet Gynecol 2012; 36-1:37-42]

Keywords: acute toxicity, concurrent chemoradiation, locoregional advanced stage cervical cancer, response therapy

\begin{abstract}
Abstrak
Tujuan: Untuk mengevaluasi dan mengetahui efek toksisitas dan respons terhadap terapi radiasi saja dibandingkan dengan kemoradiasi menggunakan cisplatin konkuren pada kanker serviks stadium lanjut lokoregional di Rumah Sakit Dr. Cipto Mangunkusumo.

Metode: Penelitian dilakukan dengan metode simpel randomized single blind, dengan sampel sejumlah 32 pasien kanker serviks stadium lanjut lokoregional (IIB-IIIB) yang memenuhi kriteria penerimaan, dari kurun waktu November 2010-April 2011. Sampel terbagi atas 2 kelompok terapi, 16 pasien masuk ke dalam kelompok terapi radiasi saja dan 16 pasien masuk ke dalam kelompok terapi kemoradiasi menggunakan cisplatin $30 \mathrm{mg} / \mathrm{m}^{2}$. Tele terapi dilakukan dengan sinar gamma ${ }^{60} \mathrm{Co} 1,3 \mathrm{MV}$ dan sinar foton akselerator linear $4-10$ megavolt. Radiasi diberikan bertahap sebanyak 2,0 Gy setiap hari 5 kali seminggu, dan diberikan sebanyak 25 kali. Brakiterapi dilakukan dengan metode after-loading HDR dengan pesawat Mikroselectron sumber radiasi ${ }^{129}$ I, dengan dosis $3 \times 7$ Gy di titik A. Penilaian toksisitas dilakukan tiap minggu sampai 3 bulan setelah terapi dinyatakan lengkap berdasarkan kriteria RTOG dan ECOG.
\end{abstract}

Hasil: Diperoleh respons yang komplit sebesar 100\% pada kelompok kemoradiasi dan radiasi. Pada kelompok yang mendapat kemoradiasi, didapatkan toksisitas akut gastrointestinal grade $3(18,75 \%)$ dan grade 2 (43,75\%); toksisitas genito urinaria grade 3 (25\%) dan grade 2 (31,25\%); serta toksisitas akut hematologi grade $3(12,50 \%)$ dan grade 2 (25\%), sementara kelompok yang mendapat terapi radiasi saja tidak ditemukan satupun kasus yang mengalami toksisitas gastrointestinal, genito urinaria maupun hematologi. Overall time treatment (OTT) 56-58 hari dicapai dalam kelompok terapi radiasi dan kemoradiasi sebesar 25\% vs 81,25\%, dan OTT 59-70 hari dicapai oleh kelomopok terapi radiasi dan kemoradiasi sebesar $75 \%$ vs $18,75 \%$.

Kesimpulan: Respons terhadap terapi kemoradiasi dibandingkan dengan terapi radiasi saja pada kanker serviks stadium lanjut lokoregional tidak menunjukkan perbedaan yang signifikan pada evaluasi 3 bulan paskaterapi. Toksisitas akut gastrointestinal kemoradiasi lebih tinggi dibanding radiasi $(p=0,000)$. Toksisitas a kut genito urinaria kemoradiasi lebih tinggi dibanding radiasi saja $(p=0,000)$. Toksisitas akut Hematologi kemoradiasi lebih tinggi dibanding radiasi $(p=0,002)$. OTT kemoradiasi lebih panjang dibandingkan radiasi $(p=0,001)$.

[Maj Obstet Ginekol Indones 2012; 35-1:37-42]

Kata kunci: kanker serviks lokoregional stadium lanjut, kemoradiasi konkuren, respons terapi, toksisitas akut

Correspondence: Rudy Gunawan, Division of Oncology Gynecology Department of Obstetrics and Gynecology Faculty of Medicine University of Indonesia/ Dr. Cipto Mangunkusumo Hospital, Jakarta. Telephone: 08127499449, email: rudyspogjbi@yahoo.com 


\section{INTRODUCTION}

Cervical cancer is the third most common cancer in women, and the seventh among all cancer, with an estimated 530,000 new cases every year and is responsible for 275,000 deaths in 2008. More than $85 \%$ of the global burden occurs in developing countries, where it accounts for $13 \%$ of all death. Overall, the mortality rate is $52 \%$ and about $88 \%$ of it occurs in developing countries. The incidence in Indonesia is about 13,762 cases and it caused approximately 7,493 deaths per year. ${ }^{1}$ According to the Ministry of Health of the Republic Indonesia in 2005 , the incidence of cancer is estimated to be in the range of 100 cases per 100,000 population or 200,000 cases annually, and more than $70 \%$ of cases came to the hospital in the advanced stage. ${ }^{2}$ Indonesia Association of Pathologists in 2006 reported that cervical cancer was the first among 10 most frequent women cancer in Indonesia, approximately 2,459 cases $^{3}$ and the mortality rate is very high because most patients present with advanced or terminal stages. ${ }^{2}$ During 2005-2010 in Dr. Cipto Mangunkusumo Hospital (RSCM), we obtained 2,297 cases of cervical cancer, and 66.4\% arrived in advanced stages (more than stage IIB). Thus, the outcomes of treatment are often disappointing. ${ }^{4}$

A Meta-analysis study of 4,850 patients (19 studies) found that receiving chemoradiation therapy increased progression-free survival and overall survival significantly, compared with radiation therapy alone. CRT with cisplatin regiment reduced the number of local metastases and distant metastases. ${ }^{5}$ However, other studies showed that the outcomes of CRT in cervical cancer were still not very satisfying, numerous studies had shown it increases only $3-6 \%$ of 5-years survival rates, but the incidence of hematologic, genitourinary and gastrointestinal toxicity increased significantly in CRT groups compared with RT only groups. ${ }^{6}$

Controversy of CRT still exists, concerning whether CRT is really feasible and effective for patients in developing countries in Asia, ${ }^{7}$ including Indonesia, for several reasons. As regard to reasons: in Phase III studies in North America and Europe, most patients have their disease status examined by computed tomography (CT) or Magnetic Resonance Imaging (MRI), but only a limited number of patients can undergo those examination in Asia, including Indonesia, because of the socioeconomic diversity problems. In studies in the United
Sates, para-aortic lymph nodes were evaluated with extra peritoneal lymphadenectomy or bipedal lymphangiography and patients who are found positive for para-aortic lymph nodes were excluded from the studies. ${ }^{6,7}$ These examination is not commonly used in Indonesia. Some other reason is the differences which might exist in supportive care for CRT between the developed and developing countries. In the phase III studies in the US in the 1990s, all patients are treated with low dose rate (LDR) intracavitary brachytherapy (ICBRT). ${ }^{7,8}$ But recently, HDR ICBRT has been performed worldwide, including in Indonesia. The combination of HDR ICBRT and CRT has been used clinically, but only few reports regarding the outcome of therapy have been published. - $^{9-11}$ Therefore, the efficacy of CRT using HDR ICBRT has not been thoroughly evaluated in the clinical setting.

Pearsy et al reported a National Cancer Institute of Canada (NCIC)-sponsored trial, in which they compare cisplatin-based CRT versus radiation therapy alone inpatients with locally advanced cervical cancer. The result has not shown any significant different outcomes of CRT vs. RT alone in locally advanced cervical cancer, both in the survival of 3 years (69\% vs. $66 \%$ ) and 5 years $(62 \%$ vs. $58 \%$ ), whereas the toxicity of the chemoradiation increased $10 \%$ compared to radiation alone. ${ }^{12} \mathrm{Si}$ milarly, a studying India by Negi et al, has show no significant difference between CRT and RT, in the evaluation complete response ( $60 \%$ vs. $50 \%$ ), partial response ( $20 \%$ vs. $23.1 \%$ ), progressive tumors ( $8 \%$ vs. $15.4 \%$ ), relapse tumors $(12 \% \text { vs } 15.4 \%)^{13}$ for 3 years. Therefore, the effectiveness of CRT combined with HDR ICBRT should be evaluated carefully, especially in Indonesia, where we have different standards procedure and socioeconomic diversity problems. We expected that this study can find the outcome and toxicity effects of CRT and RT alone in patients with locoregional advanced stage cervical cancer, improve the quality of care and evaluate the treatment for locoregional advanced stage cervical cancer in the RSCM.

\section{METHODS}

This study was a Randomized Clinical Trial (RCT), with single blind method. Subjects were patients with advanced stage locoregional cervical cancer (IIB, IIIA, IIIB) who came to the outpatient gynecology oncology clinic in RSCM, and met the criteria inclusion during the period of November 2010 to 
April 2011. Sample size is based on statistical study problem, with $\alpha=5 \%$ and $\beta=95 \%$, we obtained 32 patients for our sample population. Inclusion criterias were patients newly diagnosed with cervical cancer, who have been conducted to histopathological examination and staging according to FIGO stage IIB-IIIB, with performance status score $\leq 2$ based on the criteria of the Eastern Cooperative Oncology Group (ECOG) , have a normal peripheral blood examination result $(\mathrm{Hb} \geq 10 \mathrm{~g} \%$, leucocyte count $\geq 5,000 / \mathrm{mm} 3$, platelets $\geq 150,000 /$ $\mathrm{mm}^{3}$ ), liver function (SGOT $<27 \mathrm{U} / \mathrm{l}, \mathrm{ALT}<36 \mathrm{U} / \mathrm{l}$ ) and kidney function $(\mathrm{U}<50 \mathrm{mg} / \mathrm{dl}$, creatinine 0.6$1.20 \mathrm{mg} / \mathrm{dl}$, CCT $68-110 \mathrm{ml} / \mathrm{min}$ ), willing to participate in the study and undergoing RT or CCRT in the RSCM. Tumor mass measurement is done by 3D ultrasound (Accuvix ${ }^{\circledR} \mathrm{xQ}$, Medison, Seoul, Korea), and the tumor diameter was measured in three dimensions: the lateral width (W), dorsoventral thickness (T), and craniocaudal length (L). ${ }^{14}$ External beam radiation therapy was administered using cobalt 60 teletherapy machine. A dose of 50 Gy in 25 fractions in 5 weeks was given at the rate of 2 Gy per fraction daily, for 5 days in a week. Intra cavitary brachytherapy was performed using microselectron remote controlled HDR system, Ir based, giving a dose of 21 Gy (7 Gy per weeks in 3 weeks) to point $A .{ }^{15}$ Chemotherapy with cisplatin $30 \mathrm{mg} / \mathrm{m}^{2}$ is given intravenously once a week, 6-8 hours prior to radiation, on the first day of the week for 5 series. Assessment for the response to therapy was done 3 months after the therapy is deemed completed (according RECIST criteria) by measuring the degree of tumor regression with transrectal ultrasonography, clinical examination and cytology examination. Assessment of gastrointestinal toxicities and genitourinarius is based on Radiation Therapy Oncology Group (RTOG) criterias, whereas hematologic toxicities criteria is based on a combination of Eastern Cooperative Oncology Group (ECOG) and the Gynecologic Oncology Group (GOG) criteria. Both effects were evaluated every week. The toxicities which arising were treated according to the standard management in the Division of Gynecology Oncology and Department of Radiotherapy RSCM. All data were analyzed statistically with STATA program version 10 (Stata Corporation LP, Texas, USA). This study had been granted permission and agreement from The Committee of The Medical Research Ethics of The Faculty of Medicine, University of Indonesia, with certificate ethical clearance No: 532/PT02.FK/ETIK/2010.

\section{RESULTS}

Between November 2010-April 2011, 32 eligible patients were enrolled for this study. They were divided into 2 groups: 16 were assigned to RT and 16 to CRT. The characteristics of demogrhapy, clinical examination, and histopathology of subjects are listed in Table 1, and Table 2, respectively. With regard to chemotherapy, 6 cases $(37.50 \%)$ received 3 cycles, 5 cases $(31.25 \%)$ received 4 and 5 cycles. Meanwhile, the other 4 patients failed to receive a full 5 cycles caused by genitourinary toxicity (63.7\%) and gastrointestinal toxicity (36.3\%).

Table 1. Demography Characteristics of Subjects

\begin{tabular}{|c|c|c|c|}
\hline \multirow{3}{*}{$\begin{array}{c}\text { Characteristic } \\
\text { of } \\
\text { Demography }\end{array}$} & \multicolumn{2}{|c|}{ Therapy } & \multirow{3}{*}{$\underset{\text { value }}{\mathbf{p}}$} \\
\hline & RT & CRT & \\
\hline & n(\%) & n(\%) & \\
\hline \multicolumn{3}{|l|}{ Ages } & 0.465 \\
\hline 35 - 47 years & $5(31.2)$ & $7(43.8)$ & \\
\hline 48 - 68 years & $11(68.8)$ & $9(56.2)$ & \\
\hline \multicolumn{3}{|l|}{ Education } & 0.711 \\
\hline$\leq 6$ years & $2(75)$ & $10(62.5)$ & \\
\hline 7 - 9 years & $3(18.8)$ & $5(31.3)$ & \\
\hline $10-12$ years & $1(6.2)$ & $1(6.2)$ & \\
\hline \multicolumn{3}{|l|}{ Parity } & 0.710 \\
\hline $1-3$ & $6(37.5)$ & $5(31.2)$ & \\
\hline $4-9$ & $10(62.5)$ & $11(68.8)$ & \\
\hline \multicolumn{3}{|c|}{ Age at the fisrt sexual contact } & 0.288 \\
\hline 13 - 16 years & $6(37.5)$ & $9(56.2)$ & \\
\hline 17 - 22 years & $10(62.5)$ & $7(43.8)$ & \\
\hline
\end{tabular}

Table 2. The distribution of clinical and histopathology feature of subjects

\begin{tabular}{|c|c|c|c|}
\hline \multirow{3}{*}{$\begin{array}{c}\text { Clinical } \\
\text { Characteristics }\end{array}$} & \multicolumn{2}{|c|}{ Therapy } & \multirow{3}{*}{$\begin{array}{c}\mathbf{p} \\
\text { value }\end{array}$} \\
\hline & RT & CRT & \\
\hline & n(\%) & $n(\%)$ & \\
\hline Stage & & & 1.000 \\
\hline II B & $8(50)$ & $8(50)$ & \\
\hline III A & $1(6.2)$ & - & \\
\hline III B & $7(43.8)$ & $8(50)$ & \\
\hline Tumor Size & & & 1.000 \\
\hline$\leq 40 \mathrm{~mm}$ & $2(12.5)$ & $2(12.5)$ & \\
\hline$>40 \mathrm{~mm}$ & $14(87.5)$ & $14(87.5)$ & \\
\hline Lymph nodes & & & 0.669 \\
\hline Positive & $4(25)$ & $3(18.8)$ & \\
\hline Negative & $12(75)$ & $13(81.2)$ & \\
\hline ECOG Score & & & 1.000 \\
\hline 0 & $15(93.8)$ & $15(93.8)$ & \\
\hline 1 & $1(6.2)$ & $1(16.2)$ & \\
\hline OTT & & & 0.001 \\
\hline 56 - 58 days & $13(81.3)$ & $4(25)$ & \\
\hline 59 - 70 days & $3(18.7)$ & $12(75)$ & \\
\hline Cells Type & & & 0.365 \\
\hline Adenocarcinoma & $2(12.5)$ & $4(25)$ & \\
\hline Carcinosquamous & $14(87.5)$ & $12(75)$ & \\
\hline Diffrentiation & & & 0.911 \\
\hline Well & $3(18.8)$ & $4(25)$ & \\
\hline Moderate & $12(75)$ & $11(68.8)$ & \\
\hline Poor & $1(6.2)$ & $1(6.2)$ & \\
\hline
\end{tabular}


Table 3 showed the overall acute toxicities in our study. At 3 months post-therapy, all of the cases in RT and CRT groups showed 100\% complete response.

Table 3. Overall Acute Toxicities

\begin{tabular}{cccc}
\hline \hline Acute & RT & CRT & p \\
voxicites & $\mathbf{n ( \% )}$ & $\mathbf{n ( \% )}$ & 0.000 \\
\cline { 2 - 3 } Gastrointestinal & & & \\
Grade 0 & $3(18.7)$ & - & \\
Grade 1 & $13(81.3)$ & $6(37.5)$ & \\
Grade 2 & - & $7(43.7)$ & \\
Grade 3 & - & $3(18.8)$ & \\
Genitourinary & & & \\
Grade 0 & $16(100)$ & -000 \\
Grade 1 & - & $7(43.8)$ & \\
Grade 2 & - & $5(31.2)$ & \\
Grade 3 & - & $4(25)$ & \\
Hematology & & & \\
Grade 0 & $14(87.5)$ & $4(25)$ & \\
Grade 1 & $2(12.5)$ & $6(37.5)$ & \\
Grade 2 & - & $4(25)$ & \\
Grade 3 & - & $2(12.5)$ & \\
\hline \hline
\end{tabular}

\section{DISCUSSION}

CRT is a standard therapy for locally advanced cervical cancer in North America and in Europe, but this method has not become a standardized therapy in many Asian countries due to the differences in the patient's general status, diagnostic procedures performed, techniques of radiotherapy, tolerance to the chemotherapy and socioeconomic factors. ${ }^{7}$ In this study, we compared the response and outcome of CRT using cisplatin $30 \mathrm{mg} / \mathrm{m}^{2}$ with radiation therapy alone.

This study has advantages and limitations. One of the advantages is that the primary data directly taken through anamnesis, physical examination, gynecological examination, ultrasound and other investigations. Each case was evaluated immediately and all necessary data in accordance to objective assessment of therapeutic response was recorded. Meanwhile the limitation sare the number of samples, which is relatively small, and the fact that we have not assess the disease free survival for 1 year, recurrence rate, disease free survival and late toxicity yet. We used a total dose of 71 Gy for treatment; duration of radiotherapy, dose and method of radiation were similar among CRT and RT alone. Several studies have suggested that total length of treatment influences the efficacy of radiotherapy. ${ }^{16-}$ ${ }^{18}$ Lelieveld et al, showed that small doses of cisplatin and lower serum levels produced maximal effect ${ }^{19}$. Interactions leading to increased cell death, namely radiosensitization of hypoxic cells and inhibiting re- pair of sub lethal damage, require the presence of cisplatin prior to and after radiation therapy. Continuous infusion of the drug fulfills this requirement. The majority of randomized trials were performed by giving cisplatin few hours prior to radiation therapy. In our study, we gave cisplatin 6 - 8 hours before radiotherapy.

In the evaluation on 3 months after the treatment is completed, our study showed that CRT, though tolerated well, failed to show any difference in outcome, compared with RT alone, we found that in all cases, we achieved $100 \%$ complete response, both in CRT and RT groups. Similar result was found by Kundan SC et al. After 3 months of completion of CRT, there was no statistically significant difference in response rates among RT and CRT group ( $\mathrm{p}=0.235)$, but the survival rate at the end of 2 years were as follow: locoregional relapsefree survival is $69 \%$ vs. $61.6 \%$, DFS $68.3 \%$ vs. $59.4 \%$, OS $68.3 \%$ vs. $62.3 \%$ respectively among RT and CRT group. ${ }^{20}$ Similarly, in the study by $\mathrm{M}$. Garipa et al, tolerability and efficacy of the cisplatin continuous infusion during radiotherapy were studied. The tumor response, survival rate and pelvic control of 44 patients with stage IIB-IIIB cervical carcinoma were prospectively randomized into two groups: radiation alone versus radiation plus cisplatin. ${ }^{21}$ Tumor responses were no different in the end of the treatment and 3 months after the completion of treatment. Five-year pelvic control rates were $69.4 \%$ and $63.9 \%(\mathrm{p}=0.7)$, survival rates were $52.0 \%$ and $48.9 \%(\mathrm{p}=0.7)$, and diseasefree survival rates were $67.5 \%$ and $58.7 \%(\mathrm{p}=0.3)$ for the RT and the CRT groups, respectively. Although the continuous infusion of cisplatin during radiotherapy was well tolerated, this additional treatment in the form of CRT did not appear to show any improvement in pelvic control, survival rate, or disease-free survival rate. In our study, US abdomen was mainly used to evaluate para-aortic nodal status, which is an inferior modality compared to lymphangiography and CT scans, and we did not exclude patients with positive nodes. In our set up, it is difficult to carry out extensive work up like laparotomy, lymphangiography and CT scans due to financial issues and those procedures are not our routine protocol to manage advanced cervical cancer. Many patients may have had paraaortic nodes that were not detected with US abdomen, adding to our inferior results. Meta analysis by Green et al suggested that the benefit of CRT is more apparent in early stages and when disease is 
confined to the pelvis. ${ }^{22}$ Another factor contributing to our inferior results may be the small sample size, which may not have picked the difference of response in two treatment arms. The trial by Pearcy et al also had the smallest number of patients among all prospective randomized trials. ${ }^{12}$ The majority of treatment failures were seen in the pelvis in the irradiated area. An analysis on the pattern of failure reveals that $29.4 \%$ of those who failed had pelvic tumor as a component of first site of failure. The study conducted by Negi et al did not show any benefit of CRT when compared to RT alone in locally advanced cervical cancer patients. ${ }^{13}$ That could be due to more bulk of tumor stage per stage; poor nutritional status; less number of patients in both arms, not enough to pick up statistically significant small difference in outcome; the difference of dose and scheduling of radiotherapy or chemotherapy. Our results are also approximately similar to the results of 6 randomized multiinstitutional trial by the NCIC, which evaluate the patient on the third month of complete response on all group therapy. But in our study, we did not evaluate the 3 and 5 years survival rate because this study has not yet reached 1-year since the completion of therapy. Other similiarity with the NCIC study is that this study did not performa selection of patients on the suspicion of metastases in lymph nodes, but all patients, despite positive enlargement of lymph nodes which was found with ultrasound (4 patients in RT group and 3 patients in CRT group), were enrolled in this study.

Acute gastrointestinal and genitourinary toxicities were the principal adverse effects in our study. The frequency of grade 2 and 3 acute gastrointestinal toxicities and genitourinary toxicities was significantly higher in the CRT arm $(\mathrm{p}=0.000)$. Even though acute toxicities were found more in CRT group, they were manageable. In the majority of the patients, the GI toxicities manifested as vomiting and diarrhea, which were infrequent in RT alone group. The genitourinary toxicities manifested as nocturia happening more than 1 hour, dysuria, pelvic pain and vesica urinary spasm, which were not found in RT group. The hematology toxicity grade 2 and 3 were noted in 6 patients in CRT but were not found in RT group. Thus, there was a significant difference $(\mathrm{p}=0.002)$. Compared to the other randomized trials using cisplatin, we had less hematological complications, which may be due to lesser dose of cisplatin and 5-Fluorouracil that we used. The other factor leading to higher hematology tox- icity in other trials is the incorporation of hydroxyurea in the treatment. The most important adverse effect with cisplatinum was emesis, but it was successfully managed by one of the 5-hydroxytryptamine antagonists. In our study, genitourinary toxicity grade 1 occurred in 7 patients (43.7\%) in CRT group. No genitourinary toxicity was noted in the RT group. There was no patient death caused by concurrent cytotoxic drug therapy. Grade 3-4 gastrointestinal toxicities were higher in patients in cisplatin group in a trial by Whitney et al (8\%) as compared to $\mathrm{HU}$ group, and there were no grade 4 nephrotoxicity. Grade 3 and 4 of other toxicities were encountered less than $2 \%{ }^{8}$ In a study by Saibishkumar et al comparing patients receiving CRT to RT, severe acute toxicities (grade $3 \geq$ RTOG criteria) were significantly higher in CRT arm (31.6 $\%)$ compared to the RT groups (11.6\%), with $\mathrm{p}$ value $<0.001$. The occurence rate of hematologic toxicity of grade 2 anemia, neutropenia and thrombocytopenia were $11.4 \%, 31.4 \%$ and $2.8 \%$, respectively. ${ }^{23}$ LT Tan et al showed that CRT using cisplatin had higher toxicity than RT alone but still had a good tolerance when given to the population of cervical cancer carried out without selection. ${ }^{24} \mathrm{We}$ also tried to link the OTT with the overall acute toxicity occurring in patients during therapy, and there was a significant difference between the two groups of OTT with the acute toxicities gastrointestinal, hematologic and genitourinary $(\mathrm{p}=0.003 ; \mathrm{p}=0.005$ and $\mathrm{p}=0.008$ ) respectively. In this study, we found a significant differences between the two treatment groups against the cost of therapy with $p$-value $=$ 0.000 . Significant differences are due to the addition cost of the chemotherapy drug and the incremental cost of hospitalization because patients receiving chemotherapy require hospitalization of at least one day for one series. And also adding to the cost is drugs, functioned as an anticipation of events that will result in toxicity effects, which are given together during chemotherapy administration.

OTT is one of the prognostic factors in radio-therapy for cervical cancer. Nag $S$ et al, recommend that the OTT should not exceed 56 days. ${ }^{25}$ Doses of radiation in the others study protocols used 80 Gy to point A with the OTT anticipated 49 to 70 days. Some studies suggest that OTT affected the success of radiation. ${ }^{18-20}$ This study obtained the ranges of OTT were 56-59 days with median 56.2 days in RT group, 58-70 days with median 63.5 days in CRT group. It was significantly different duration OTT with both of the arms ( $p=0.001)$. 


\section{CONCLUSION}

The outcomes of CRT group and RT group were similar in patients with advanced locoregional cervical cancer on evaluation at 3 months after completion of therapy. The incidences of acute gastrointestinal, genitourinary and acute hematologic toxicities in CRT group were higher than RT alone, with a significant difference $(p=0.000, p=0.00$, $\mathrm{p}=0.002)$. Overall Treatment Time (OTT) in CRT group is longer than in RT group $(\mathrm{p}=0.001)$. Our study could still be improved by evaluating the patient for a longer time, in order to determine the disease free survival (DFS), overall survival, recurrence rate, relapse free survival and late toxicity.

\section{REFERENCES}

1. Ferlay J, Shin HR, Bray F, Forman D, Mathers C, Parkin DM. GLOBOCAN 2008 v1.2, Cancer Incidence and Mortality Worldwide: IARCnCancer Base. Lyon France: International Agency for Research on Cancer, 2010. Available from: http://gobocan.iarc.fr. Accesed May 2011.

2. Direktorat Jenderal Pelayanan Medik Departemen Kesehatan RI. Penanggulangan Kanker Serviks dengan Vaksin HPV. Departemen Kesehatan RI; 2005.

3. Yayasan Kanker Indonesia. Kanker di Indonesia Tahun 2006 Data Histopatologik. Jakarta: Direktorat Jenderal Pelayanan Medik Departemen Kesehatan RI. Badan Registrasi Kanker Perhimpunan Dokter Spesialis Patologi Indonesia; 2006.

4. Laila N, Chaterine, Farit Aziz, Andrijono, Sigit Purbadi, Tricia Anggreini, et al. Distribution of Age, Stage, and Histopathology of Cervical Cancer: A Retrospective study on Patients at Dr. Cipto Mangunkusumo Hospital. Jakarta, Indonesia, 2006-2010. Indones J Obstet Gynecol 2011; 35:21-4.

5. Vale C, Tierney JF, Steward LA, Brady M, Dinshaw K, Jakobsen A. Reducing uncertainties about the effect of chemoradio therapy for cervical cancer: A systematic review and meta-analysis of individual patient data from 18 randomized trial. J Clin Oncol 2008; 35:5802-12.

6. Loizzi V, Cormio G, Loverro C, Selvaggi L, Disaia J, Capuccini F. chemoradiation: Anew approach for the treatment of cervical cancer. Int J Gynecol Cancer 2003; 13:580-6.

7. Kato S, Ohno T, Thephamongkhol K. Multi-Institusional Phase II Clinical Study of Concurrent Chemoradiotherapy for Locally Advanced Cervical Cancer in East and South east Asia. Int J.Radiat Oncol Biol Phys 2010; 77:751-7.

8. Withney CW, Sause W, Bundi BN, Malfetano JH, Hannigan EV, Fowler WJ Jr. Randomized comparison of fluorouracil plus cisplatin versus hidroxyurea as an adjuct to radiation therapy in stage IIB-IVA carcinoma of the cervix with negative para-aortic lymph node: A Gynecologic Oncology Group and Southwest Oncology Group study. J Clin Oncol 1999; 17:1339-48.

9. Morris M, Eifel PJ, Lu J, Grigsby PW, Levenback C, Stevens $\mathrm{RE}$, et al. Pelvic radiation with concurrent chemotherapy compared with pelvic and para-aortic radiation for highrisk cervical cancer. N Engl J Med 1999; 340:1137-43.

10. Parkin DM, Pisani P, Ferlay J. Estimates of the worldwide incidence of the major cancers in 1990. Int J Cancer 1999; 80:827-41.
11. Toita T, Moromizato H, Ogawa K, et al. Concurrent chemoradiotherapy using high-dose-rate intracavitary brachy-therapy for uterine cervical cancer. Gynecol Oncol. 2005; 96(3):665-70.

12. Rose PG, Bundy BN. Chemoradiation for Locally Advanced cervical cancer: Does It help? J Clin Oncol 2002; 20:891-3.

13. Negi RR, Manish G, Kumar M, Gupta MK, Seam R, RastoguM, et al. Concurrent chemoradiation in locally advanced carcinoma cervix patients. J Cancer Res Ther 2010; 6:159-66.

14. Oken MM, Creech RH, Tormey DC, Horton J, Davis TE, McFadden E.T, Carbone, PP. Toxicity And Response Criteria Of The Eastern Cooperative Oncology Group. Am J Clin Oncol 1982;5:649-55

15. Sastroasmoro S, Soehartati. Panduan Pelayanan Medis Departemen Radioterapi RSUPN Dr. Cipto Mangunkusumo, Jakarta 2007:63-71.

16. Lanciano R, Calkins A, Bundy BN, Parham G, Lucci JA, III, Moore DH, et al. Randomized comparison of weekly cisplatin or protracted venous infusion of fluorouracil in combination with pelvic radiation in advanced cervix cancer; a Gynecologic Oncology Group study. J Clin Oncol. 2005; 23:8289-95.

17. Ohara K, Tanaka YO, Tsunoda H, Oki A, Satoh T, Onishi K, et al. Preliminary estimation of treatment effect on uterine cervical squamous cell carcinoma in terms of tumor regression rate. Rad Med 2005; 23:25-9.

18. Rose PG, Bundy BN, Watkins EB, Thigpen TJ, Deppe G, Maiman MA, et al. Concurrent cisplatin-based radiotherapy and chemotherapy for locally advanced cervical cancer. N Engl J Med 1999; 340:1144-53.

19. Lelieveld P, Scoles MA, Brown JM, Kallman RF. The effect of treatment in fractionated schedules with the combination of Xirradiation and six cytotoxic drugs on the RIF-1 tumour and normal mouse skin. Int J Radiat Oncol Biol Phys 1985;11:111-21.

20. Kundan CS, Chufal, Madhup Rastogi, Srivastava M, Pant MC, Bhatt MLB, Srivastava K. Concurrent chemoradiotherapy for locally advanced cervical cancer using Gemcitabine: non-randomized comparison of three sequential protocols. Cancer Therapy 2007; 5:43-54.

21. Garipagaoglu M, Kayikcioglu F, Kose MF, Adli M, Gulkesen $\mathrm{KH}$, Kocak Z. Adding concurrent low dose continuous infusion of cisplatin to radiotherapy in locally advanced cervical carcinoma: A prospective randomized pilot study. Br J Radiol 2004; 77:581-7.

22. Green JA, Kirwan JM, Tierney JF, Symonds P, Fresco L, Collingwood M, et al. Survival and recurrence after concomitant chemotherapy and radiotherapy for cancer of the uterine cervix: A systematic review and meta-analysis. Lancet 2001; 358:781-6.

23. Saibishkumar EP, Patel FD, Sharma SC. Result of a phase II trial of concurrent chemoradiation in the treatment of locally advanced carcinoma of uterine cervix: An experience from India. Bull Cancer 2005; 92:E7-12.

24. Tan LT, Russel S, Burgess L. Acute toxicity of Chemo-radiation for cervical cancer: The Adden Brooke's Experience. Clin Oncol 2004; 16:255-60.

25. Nag S, Chao C, Erickson B, Fowler J, Gupta N, Martinez A, et al. The American Brachy therapy Society recomendations for low dose rate brachytherapy for carcinoma of the cervix. Int J Radiat Oncol Biol Phys 2002; 52:33-48. 